\title{
When Imitation Is the Sincerest Form of Flattery: Private Label Products and the Role of Intention in Determining Trade Dress Infringement
}

\author{
Andrew Corydon Finch $\dagger$
}

Private label imitations of brand name products have become a familiar sight on the shelves of supermarkets and large, chain drugstores. ${ }^{1}$ These products bear a retailer's own private brand name but otherwise mimic the overall appearance, or "trade dress,"2 of leading brand name products by copying the sizes, shapes, colors, and labeling of those brand name products. By imitating the trade dress of brand name competitors, manufacturers of private label products make it easier for the consumer to recognize their goods for what they are: lower-priced alternatives to brand name products. ${ }^{3}$

In this way, private label manufacturers can profit from brand name manufacturers' investments in promoting consumer recognition of the trade dresses of their brand name products. ${ }^{4}$ At the same time, however, private label manufacturers can

$\dagger$ B.A. 1991, University of California, Berkeley; M.A. 1994, University of California, Los Angeles; J.D. Candidate 1997, The University of Chicago.

1 See Gabriella Stern, Cheap Imitation: Perrigo's Knockoffs Of Name-Brand Drugs Turn Into Big Sellers, Wall St J A1, A1 (July 15, 1993) (noting that a leader in private label manufacturing "supplies no less than 857 knockoffs of major brands to chains like Wal-Mart Stores Inc., Kmart Corp., and Rite Aid Corp.").

2 "The 'trade dress' of a product is essentially its total image and overall appearance ... and may include features such as size, shape, color or color combinations, texture, graphics, or even particular sales techniques." Two Pesos, Inc. v Taco Cabana, Inc., 505 US 763, 764 n 1 (1992) (citations omitted).

3 See Stern, Cheap Imitation, Wall St J at A1 (cited in note 1) (quoting Michael J. Jandernoa, Chairman and CEO of a leading private label manufacturer, stating that "[o]ur focus is on being similar but not being the same-to help the consumer see what it's comparable to").

- See Smithkline Beckman Corp v Pennex Products Co., 605 F Supp 746, 748 (E D Pa 1985) ("Private label brands owe their existence to the advertising and promotion efforts of the national brand. The national brand will expend tremendous sources of funds to build consumer recognition of both its product and tradename. ... The store brand plays upon [this] increased consumer awareness ....."). 
benefit consumers by informing them that cheaper alternatives to brand name products are available in the marketplace.

If a private label product imitates the trade dress of its brand name competitor too closely, however, the manufacturer of the private label product may be liable for trade dress infringement. Ultimately, whether there is infringement depends upon whether the two trade dresses are so similar that they create a likelihood of confusion among consumers. ${ }^{5}$ Courts generally agree that there are a number of factors to be considered in determining whether a likelihood of confusion exists. Courts also agree that the defendant's intention is one of those factors. There is considerable disagreement, however, concerning the appropriate inferences to be drawn from the defendant's intention. Some courts presume a likelihood of confusion from the mere fact of intentional copying. Other courts presume a likelihood of confusion only from a deliberate attempt to confuse consumers and thereby benefit from the plaintiff's reputation and goodwill. Finally, some courts decline to presume anything at all from either the intent to copy or the intent to confuse, but nonetheless recognize the defendant's intent as a relevant factor.

This Comment argues that courts should not presume a likelihood of confusion from a private label manufacturer's intentional copying of the trade dress of a brand name product. Section I discusses protection of trade dress under $\S 43(\mathrm{a})$ of the Lanham Act. ${ }^{6}$ This Section also discusses the difficulty inherent in applying the Lanham Act's "likelihood of confusion" test and describes how courts have attempted to overcome this difficulty. Section II examines and criticizes the different ways courts have treated intention in determining likelihood of confusion. Section III then argues that courts should not presume a likelihood of confusion from intentional copying in the private label context because a private label manufacturer's intentional imitation of trade dress, like the use of a competitor's trade name on a product for comparative purposes, can perform the useful function of informing consumers that the private label product is a cheaper alternative to its brand name counterpart.

${ }^{6}$ See Lanham Act § 43(a), codified at 15 USC § 1125(a) (1994). See Section I of this Comment for a more thorough discussion of the legal standard. 
I. TRADE DRess Protection UNDER § 43(A) OF THE LANHAM ACT

\section{A. The Evolution of $\S 43(a)^{7}$}

In 1946, Congress enacted the Trademark Law Act, more commonly known as the Lanham Act ("Act"). ${ }^{8}$ The Act was intended to protect the public by ensuring that consumers could confidently rely on a trademark as an indicator of a product's quality and origin. The Act was also intended to protect businesses by ensuring that their investments in promoting their products would not be misappropriated by "pirates and cheats." Ultimately, the Act's goal was "to protect the public from deceit, to foster fair competition, and to secure to the business community the advantages of reputation and good will by preventing their diversion from those who have created them to those who have not."

Under the original language of $\S 43$ (a) of the Act, any person who used "in connection with any goods or services ... a false designation of origin, or any false description or representation" could be held liable in a civil action "by any person who believe[d] that he [was] likely to be damaged" by such use. ${ }^{11} \mathrm{Al}-$ though $\S 43$ (a) was "[n]arrowly drawn and intended to reach false designations or representations as to the geographical origin of products, the section [was] widely interpreted to create, in essence, a federal law of unfair competition." This "federal law of unfair competition," however, provided a remedy not only for claims of false designation of origin, and false description or representation, but also for claims of trademark and trade dress infringement. ${ }^{13}$ Furthermore, for all of these claims, the "ulti-

7 Much of the following discussion is adapted from Justice Stevens's concurring opinion in Two Pesos, Inc. $v$ Taco Cabana, Inc., in which he traced the development of $\S$ 43(a) of the Lanham Act through its 1988 amendment. 505 US 763, 776, 777-84 (1992).

8 Pub L No 489, 60 Stat 427 (1946), codified as amended at 15 USC $\S 1125$ et seq (1994).

- Providing for the Registration and Protection of Trade-Marks Used in Commerce, to Carry Out the Provisions of Certain International Conventions, S Rep No 1333, 79th Cong, 2d Sess 3 (1946), reprinted in 1946 USCCAN 1274, 1274.

${ }_{10}$ Id at 4, 1946 USCCAN at 1275.

115 USC $\$ 1125$ (a) (1982), quoted in Two Pesos, 505 US at 777 (Stevens concurring).

12 Two Pesos, 505 US at 780 (Stevens concurring), quoting The United States Trademark Association Trademark Review Commission Report and Recommendations to USTA President and Board of Directors, 77 Trademark Rep 375, 426 (1987).

${ }_{13}$ Two Pesos, 505 US at 780 (Stevens concurring), citing Jerome Gilson, 1 Trademark Protection and Practice § 2.13 at 2-178 (Matthew Bender 1991). See also Trademark Law Revision Act of 1988, S Rep No 100-515, 100th Cong, 2d Sess 40 (1988), reprinted in 1988 
mate test" was the same: "whether the public [was] likely to be deceived or confused . ..."14

In 1988, Congress amended $\S 43(\mathrm{a})$, in effect codifying the courts' interpretation..$^{15}$ In so doing, "Congress approved and confirmed the extensive judicial development under the provision, including its application to trade dress that the federal courts had come to apply."16 To this end, "Congress broadened the language of $\S 43$ (a) to make explicit that the provision prohibits 'any word, term, name, symbol, or device, or any combination thereof' that is 'likely to cause confusion ....'"17 Thus, the amendment "makes clear that a confusingly similar trade dress is actionable under $\S 43(\mathrm{a})$." ${ }^{\text {18 }}$ Furthermore, it establishes that the test for infringement is whether two trade dresses are so similar as to create a likelihood of confusion among consumers. ${ }^{19}$

\section{B. Proving a Likelihood of Confusion}

The "likelihood of confusion" test is difficult to apply. This difficulty arises from requiring courts to determine the probability that a broad and diverse class of persons (consumers), who are

USCCAN 5577, 5603 (noting that $\S 43(a)$ "has been applied to cases involving the infringement of unregistered marks, violations of trade dress and certain nonfunctional configurations of goods").

14 Two Pesos, 505 US at 780 (Stevens concurring), quoting New West Corp v NYM Co. of California, Inc., 595 F2d 1194, 1201 (9th Cir 1979).

15 Trademark Law Revision Act of 1988, Pub L No 100-667, 102 Stat 3935, codified at 15 USC \& 1125(a). The amended statute provides that:

Any person who, on or in connection with any goods or services, or any container for goods, uses in commerce any word, term, name, symbol, or device, or any combination thereof, or any false designation of origin, false or misleading description of fact, or false or misleading representation of fact, which-

(A) is likely to cause confusion, or to cause mistake, or to deceive as to the affiliation, connection, or association of such person with another person, or as to the origin, sponsorship, or approval of his or her goods, services, or commercial activities by another person ... shall be liable in a civil action by any person who believes that he or she is or is likely to be damaged by such act.

See also Trademark Law Revision Act at 40, 1988 USCCAN at 5603 (cited in note 13) (indicating that the amendment of $\S 43$ (a) was intended "to codify the interpretation it has been given by the courts").

${ }^{16}$ Two Pesos, 505 US at 783 (Stevens concurring).

17 Id, quoting 15 USC $\$ 1125$ (a).

18 Two Pesos, 505 US at 783 (Stevens concurring).

19 Although "likelihood of confusion" is the test for infringement under $\S 43(a)$, the plaintiff must first establish that its trade dress is eligible for protection. In order to prove this, the plaintiff must show that its trade dress is nonfunctional and is either inherently distinctive or has acquired distinctiveness. See Two Pesos, 505 US at 769. 
not parties to the lawsuit, will have a certain state of mind (confusion). ${ }^{20}$ Defining the relevant class of consumers is a difficult task in itself. Should careless consumers be included in this class, or should it be limited to ordinarily prudent consumers? Should all potential consumers be included, or only consumers who are likely to purchase the product in question? ${ }^{21}$ Once these questions are answered and the class is defined, one must ask how many consumers within that class must be likely to be confused in order for there to be infringement. ${ }^{22}$ And it is a similarly difficult task to define the relevant time of confusion. Should confusion be considered at the time of purchase only? Or should confusion after the point of sale also be considered? ${ }^{23}$ Finally, since the test focuses on the probability that consumers will be confused, "there is no specific event or action to be proved by direct evidence." ${ }^{.24}$ As a result, proof of likely confusion "must ultimately rest on the inference[s] to be drawn from circumstantial evidence. ${ }^{25}$

To overcome these difficulties, courts consider a number of different factors to be relevant in determining whether a challenged trade practice creates a likelihood of confusion. ${ }^{26}$ The first court to recognize these factors was the Second Circuit in Polar-

${ }^{20}$ Harvey S. Perlman, The Restatement of the Law of Unfair Competition: A Work In Progress, 80 Trademark Rep 461, 471 (1990).

${ }^{21}$ Compare L.A. Gear, Inc. v Thom McAn Shoe Co., 988 F2d 1117, 1134 (Fed Cir 1993) (Since "[p]urchasers in discount stores are sufficiently sophisticated . . . to know whether they are buying the cheaper copies or the expensive originals," there was no likelihood of confusion.), with Esercizio v Roberts, 944 F2d 1235, 1244-45 (6th Cir 1991) (holding that members of the public, not just Ferrari purchasers, were the relevant class of consumers for the purpose of determining likelihood of confusion). See generally Michael J. Allen, The Scope of Confusion Actionable Under Federal Trademark Law: Who Must be Confused and When?, 26 Wake Forest L Rev 321 (1991) (analyzing the question of who must be confused for trademark infringement to be actionable under the Lanham Act).

22 William M. Landes and Richard A. Posner, Trademark Law: An Economic Perspective, $30 \mathrm{~J} \mathrm{~L} \&$ Econ 265, 304 (1987).

${ }_{23}$ See, for example, Levi Strauss \& Co. v Blue Bell, Inc., 632 F2d 817, 822 (9th Cir 1980) (noting that a paper "billboard" affixed to Wrangler pants would be removed by the purchaser and thus would not prevent confusion of prospective purchasers who might see the pants being worn after the point of sale).

${ }_{24}$ Perlman, 80 Trademark Rep at 471 (cited in note 20 ).

25 Id.

${ }^{26} \mathrm{~J}$. Thomas McCarthy, McCarthy on Trademarks and Unfair Competition § 24.06[4][a] at 24-49 to 24-57 (Clark Boardman Callaghan 1995) (including a thorough survey of the factors employed by various circuits, citing cases). See also Michael $\mathrm{H}$. Bierman and Jeffrey D. Wexler, Toward a Reformulation of the Test for Determining Trademark Infringement, 80 Trademark Rep 1, 3-14 (1990) (collecting and comparing lists of factors from every circuit except the Federal and D.C. Circuits with regard to trademark infringement). 
oid Corp v Polarad Electronics Corp. ${ }^{27}$ Although Polaroid involved a claim of trademark infringement under a different provision of the Lanham Act, the factors articulated by Judge Friendly (or variations thereof) have become the standard by which courts determine whether a challenged trade practice creates a likelihood of confusion under $\S 43(\mathrm{a}){ }^{28}$ Indeed, most circuits have established their own lists of factors to be applied to trademark infringement claims, so "[i]t is now a required ritual for courts in trademark infringement cases to consider and weigh each of the relevant factors before reaching a decision."29

Most circuits apply the same factors to trade dress infringement claims as well. While each of these circuits recognizes a slightly different set of factors, the list usually includes (1) the strength of the plaintiff's trade dress; ${ }^{30}(2)$ the similarity of the plaintiff's and the defendant's trade dresses; ${ }^{31}$ (3) the similarity of the plaintiff's and the defendant's products; ${ }^{32}$ (4) the similarity of the advertising media used by the parties; ${ }^{33}(5)$ the likely sophistication and degree of care exercised by consumers; ${ }^{34}(6)$ evi-

27287 F2d 492, 495 (1961). See also Perlman, 80 Trademark Rep at 470-71 (cited in note 20 ), noting that the Second Circuit adopted these factors from the Restatement of Torts $\S \S 728-32$ (1938).

${ }_{28}$ Joel W. Reese, Defining the Elements of Trade Dress Infringement under Section 43(a) of the Lanham Act, 2 Tex Intell Prop I J 103, 123-24 (1994).

29 Perlman, 80 Trademark Rep at 471 (cited in note 20).

30 See, for example, Paddington Corp v Attiki Importers \& Distributors, Inc., 996 F2d 577, 584 (2d Cir 1993); Versa Products Co. v Bifold Co. (Manufacturing) Ltd., 50 F3d 189, 202-04 (3d Cir), cert denied, 116 S Ct 54 (1995); Esercizio, 944 F2d at 1242 (Sixth Circuit); Conopco, Inc. v May Department Stores Co., 784 F Supp 648, 678 (E D Mo 1992), rev'd in part, 46 F3d 1556 (Fed Cir 1994), cert denied, 115 S Ct 1724 (1995) (listing Eighth Circuit factors); First Brands Corp v Fred Meyer, Inc., 809 F2d 1378, 1384 n 6 (9th Cir 1987); Ambrit, Inc. $v$ Kraft, Inc., 812 F2d 1531, 1538 (11th Cir 1986). For an explanation of the "strength" of a trademark-and the greater protection afforded stronger marks-see McCarthy, Trademarks $\S 24.06[8]$ at 24-65 to 24-68 (cited in note 26).

${ }^{31}$ See, for example, Paddington, 996 F2d at 584 (Second Circuit); Versa, 50 F3d at 202-03 (Third Circuit); Cheuron Chemical Co. v Voluntary Purchasing Groups, Inc., 659 F2d 695, 703 (5th Cir 1981); Esercizio, 944 F2d at 1242 (Sixth Circuit); Schwinn Bicycle Co. $v$ Ross Bicycles, Inc., 870 F2d 1176, 1185 (7th Cir 1989); Conopco, 784 F Supp at 678 (listing Eighth Circuit factors); First Brands, 809 F2d at 1384 n 6 (Ninth Circuit); Ambrit, 812 F2d at 1538 (Eleventh Circuit).

${ }^{32}$ See, for example, Paddington, 996 F2d at 584 (Second Circuit); Chevron, 659 F2d at 703 (Fifth Circuit); Esercizio, 944 F2d at 1242 (Sixth Circuit); Schwinn, 870 F2d at 1185 (Seventh Circuit); Conopco, 784 F Supp at 678 (listing Eighth Circuit factors); First Brands, 809 F2d at 1384 n 6 (Ninth Circuit); Ambrit, 812 F2d at 1538 (Eleventh Circuit).

${ }^{33}$ See, for example, Versa, 50 F3d at 202, 208 (Third Circuit); Cheuron, 659 F2d at 703 (Fifth Circuit); Schwinn, 870 F2d at 1185 (Seventh Circuit); Ambrit, 812 F2d at 1538 (Eleventh Circuit).

${ }^{34}$ See, for example, Paddington, 996 F2d at 584 (Second Circuit); Versa, 50 F3d at 202, 204-05 (Third Circuit); Esercizio, 944 F2d at 1242 (Sixth Circuit); First Brands, 809 F2d at 1384 in 6 (Ninth Circuit). 
dence of actual confusion; ${ }^{35}$ and (7) the defendant's intent in adopting its trade dress. ${ }^{36}$ Of all these factors, the last is the most troublesome, for it is unclear what reasonable inference can be drawn about the likelihood of consumer confusion from the defendant's intent in adopting its trade dress. As one commentator has observed, "[t]he ambiguous inference to be drawn from intentional copying of another's mark has created a confused and diverse caselaw. ${ }^{37}$

\section{The ROLE OF DEFENDANTS' INTENTIONS IN FINDING A LIKELIHOOD OF CONFUSION}

Judge Learned Hand has been credited with being "one of the first to spell out clearly the interrelationship between intent, similarity and likelihood of confusion. ${ }^{138}$ Although he may indeed have been one of the first explicitly to presume a likelihood of confusion from intentional copying, his failure to explain that interrelationship with clarity has undoubtedly contributed to the confusion of the case law.

\section{A. A $M y$-T Fine Mess}

In My-T Fine Corp $v$ Samuels, the plaintiff, a manufacturer of chocolate pudding mix sold in a "red and green package," brought an action to enjoin the defendants from manufacturing and selling pudding mix in a similar package. ${ }^{39}$ The district court found that the two packages were not similar enough to warrant a preliminary injunction. The Second Circuit reversed.

Judge Hand began his analysis by observing that the record was devoid of any evidence that consumers had been deceived. The plaintiff had "proved no more than that the boxes look a good deal alike, and that confusion may well arise. ${ }^{340}$ Further-

${ }^{35}$ See, for example, Paddington, 996 F2d at 584 (Second Circuit); Versa, 50 F3d at 202, 205 (Third Circuit); Chevron, 659 F2d at 703 (Fifth Circuit); Esercizio, 944 F2d at 1242 (Sixth Circuit); Schwinn, 870 F2d at 1185 (Seventh Circuit); Conopco, 784 F Supp at 678 (listing Eighth Circuit factors); First Brands, 809 F2d at 1384 n 6 (Ninth Circuit); Ambrit, 812 F2d at 1538 (Eleventh Circuit).

${ }^{36}$ See, for example, Paddington, 996 F2d at 584 (Second Circuit); Versa, 50 F3d at 202, 205-08 (Third Circuit); Chevron, 659 F2d at 703 (Fifth Circuit); Esercizio, 944 F2d at 1242 (Sixth Circuit); Schwinn, 870 F2d at 1185 (Seventh Circuit); Conopco, 784 F Supp at 678 (listing Eighth Circuit factors); First Brands, 809 F2d at 1384 n 6 (Ninth Circuit); Ambrit, 812 F2d at 1538 (Eleventh Circuit).

${ }^{37}$ Perlman, 80 Trademark Rep at 467 (cited in note 20).

38 McCarthy, Trademarks § 23.34[3] at 23-218 (cited in note 26).

3969 F2d 76, 76-77 (2d Cir 1934).

${ }^{40}$ Id at 77. 
more, "were it not for the evidence of the defendants' intent to deceive and so to secure the plaintiff's customers," the court would not have felt justified in interfering. ${ }^{41}$ But the court did interfere because:

[W] hen [that intent] appears, ... it has an important procedural result; a late comer who deliberately copies the dress of his competitors already in the field, must at least prove that his effort has been futile. Prima facie the court will treat his opinion so disclosed as expert and will not assume that it was erroneous. . . . He may indeed succeed in showing that it was; that, however bad his purpose, it will fail in execution; if he does, he will win. ${ }^{42}$

Judge Hand went on to describe how the evidence supported the conclusion that the defendants had deliberately copied the plaintiff's trade dress "as far as they dared." 33 The defendants had copied the directions from the plaintiff's package, which "proves that the box had been before them when they designed their own make-up ...."44 Furthermore, the defendants copied the solid green body and red lettering of the plaintiff's package. But what truly "put their intent beyond question" was that the defendants added "red stripes at every edge" of their package, just as the plaintiff had done. ${ }^{45}$ From this evidence of deliberate copying, Judge Hand concluded that the defendants "could only have meant to cause confusion, out of which they might profit by diverting the plaintiff's customers. This being the intent, the dissimilarities between the two [packages] do not ... rebut the presumption." 46

$M y$ - $T$ Fine is anything but a clear exposition of "the interrelationship between intent, similarity and likelihood of confusion." ${ }^{37}$ The court begins with the premise that the defendants' package is so similar to the plaintiff's package that the defendants must have copied the plaintiff's package. And the ultimate conclusion is that the two packages are so similar that consumers will likely be deceived. The inferential steps in between, and the exact nature of the presumptions underlying them, are far from 
clear. Throughout the opinion, Judge Hand equivocally refers to the intention to deceive, the intention to copy, and the intention to confuse without explaining the relation between them or even indicating whether they are conceptually distinct in this context. As a result, there are at least three plausible ways to interpret the opinion, each of which has different consequences for shifting to the defendant the burden of proof regarding the likelihood of confusion.

The broadest-and perhaps most prevalent-interpretation of My-T Fine is that intentional copying alone raises a presumption of a likelihood of confusion. This interpretation finds support in Judge Hand's oft-quoted statement that "a late comer who deliberately copies the dress of his competitors already in the field, must at least prove that his effort has been futile. ${ }^{348} \mathrm{How}$ ever, this statement is ambiguous: it is unclear whether the defendant must prove that his effort to copy his competitor's dress has been futile, or must prove that his effort to cause confusion has been futile. Surely, the burden on the defendant cannot be to prove that, despite his effort to copy his competitor's trade dress, he has failed to do so. After all, one who sets out to copy a competitor's trade dress can hardly fail to do so-although one might indeed make a very poor copy that will fail to confuse consumers. Thus, the defendant's burden must be to prove that, despite his effort to cause confusion, he has failed to do so.

According to this interpretaton of $M y$-T Fine, the presumption of a likelihood of confusion does not follow directly from intentional copying. Rather, there is an intermediate inference-namely, an inference of an intent to cause confusion-drawn from the intent to copy. ${ }^{49}$ As discussed more fully below, this intermediate inference is extremely weak-for there are a number of plausible reasons why one might copy a competitor's trade dress other than to confuse consumers..$^{50}$ Pre-

48 My-T Fine, $69 \mathrm{~F} 2 \mathrm{~d}$ at 77. For another opinion by Judge Hand that supports this interpretation, see American Chicle Co. $v$ Topps Chewing Gum, Inc.:

Indeed, it is generally true that, as soon as we see that a second comer in a market has, for no reason that he can assign, plagiarized the "make-up" of an earlier comer, we need no more; for he at any rate thinks that any differentia he adds will not, or at least may not, prevent the diversion [of the plaintiff's potential customers] and we are content to accept his forecast that he is "likely" to succeed.

40 At least one commentator has suggested that this is the proper analysis of $M y-T$ Fine. See McCarthy, Trademarks § 23.34[3] at 23-219 (cited in note 26).

${ }^{50}$ See id $\S 23.34[2]$ at $23-216$ to $23-217$ (suggesting reasons why one might, in good 
suming a likelihood of confusion from intentional copying thus sets a very low evidentiary threshold for claims of trade dress infringement: once the plaintiff shows that the defendant intentionally copied the plaintiff's trade dress, the burden shifts to the defendant to prove there is no likelihood of confusion.

Another interpretation of $M y$-T Fine is that the intention to copy, standing alone, does not raise a presumption of a likelihood of confusion unless there is no other plausible explanation for copying than an intention to confuse. This interpretation finds support in Judge Hand's statement that, since the defendants "had not the slightest original interest in the colors chosen and their distribution, they could only have meant to cause confusion, out of which they might profit by diverting the plaintiff's customers." ${ }^{n 1}$ Presuming a likelihood of confusion from intentional copying only in the absence of another plausible explanation requires a greater evidentiary showing by the plaintiff before shifting the burden of proof to the defendant than does the approach presuming a likelihood of confusion from the mere intent to copy.

A final interpretation of $M y$-T Fine is that the only intention that raises a presumption of a likelihood of confusion is the intention to deceive or confuse. This interpretation follows from Judge Hand's statement that "were it not for the evidence of the defendants' intent to deceive and so to secure the plaintiff's customers, we should scarcely feel justified in interfering." this interpretation, Judge Hand's statement that "a late comer who deliberately copies the dress of his competitors already in the field, must at least prove that his effort has been futile"53 should be read as meaning that a late comer who deliberately copies his competitors' trade dress with the intent to deceive or confuse will be presumed to have succeeded. This is the narrowest plausible interpretation of My-T Fine and it sets the highest evidentiary threshold for shifting to the defendant the burden of disproving a likelihood of confusion: under this approach, the

faith, copy the trade dress or trademark of another). See also text accompanying notes 6671. Judge Hand was suspicious of such "good-faith" copying. See American Chicle, 208 F2d at 562.

${ }^{32}$ My-T Fine, 69 F2d at 77 (emphasis added). The Fifth Circuit adopted this version of the presumption in Chevron Chemical Co. $v$ Voluntary Purchasing Groups, Inc., 659 F2d 695, 704 (5th Cir Oct 1981). See text accompanying notes 71-72.

${ }^{52}$ My-T Fine, 69 F2d at 77. This interpretation is also supported by the statement that "were it not for the intent to trade unfairly, we might hesitate [to interfere]." Id at 78.

53 Id at 77. 
plaintiff must show that the defendant actually intended to deceive or confuse consumers.

Although $M y-T$ Fine is itself somewhat confused and is susceptible to several different interpretations, it "has received a warm reception in the courts." ${ }^{.54}$ Indeed, one commentator's observation that $M y-T$ Fine "is now an integral part of the fabric of trademark analysis" applies equally well to the courts' analysis of trade dress. ${ }^{55}$ Furthermore, as the following discussion demonstrates, the case law reflects much of the same confusion regarding the proper role of the defendant's intention in determining trade dress infringement.

\section{B. The Role of Defendants' Intentions in Determining Likelihood} of Confusion under $\S 43(\mathrm{a})$

Almost every circuit recognizes the defendant's intent as a factor in determining likelihood of confusion in the trademark context. ${ }^{56}$ Most of these circuits also recognize the defendant's intent as a factor in determining trade dress infringement under $\S 43(a){ }^{57}$ In some of these circuits, however, the defendant's intent is more than just one factor among many. Several circuits have held that intentional copying of trade dress, without more, raises a presumption of a likelihood of confusion. Other circuits have held that, while mere intentional copying is not enough on its own, copying with the intent to deceive or confuse consumers is sufficient to raise such a presumption. A few circuits, however, reject all such presumptions and recognize the defendant's intention as only one factor among many to be considered in determining whether there is any likelihood of confusion.

\section{Intent to copy raises presumption.}

The Second Circuit has often followed the broadest interpretation of $M y-T$ Fine and has recognized a rebuttable presumption of a likelihood of confusion arising from the intentional copying of

54 McCarthy, Trademarks $\S 23.34[3]$ at 23-219 (cited in note 26).

ss See id $\S 23.34$ [3] at 23-219 \& n 18 (citing trade dress cases). See also M. Kramer Manufacturing Co. $v$ Andrews, 783 F2d 421, 448 n 24 (4th Cir 1986) (citing authorities).

${ }^{56}$ See Bierman and Wexler, 80 Trademark Rep at 30 (cited in note 26). Bierman and Wexler list the factors employed by the First through Eleventh Circuits (and cite cases). The defendant's intent (or "good faith") is a factor in each of these circuits. Bierman and Wexler also note that the Federal Circuit does not have its own list of factors and that the D.C. Circuit has yet to adopt such a list. Id at $30 \mathrm{n} 59$.

${ }^{57}$ See note 36. 
a trade dress. ${ }^{58}$ In Perfect Fit Industries, Inc. $v$ Acme Quilting Co., for example, the court noted that whether the defendant intentionally copied the trade dress of the plaintiff's mattress pads was important in determining whether there was a likelihood of confusion because "[i]f there was intentional copying the second comer will be presumed to have intended to create a confusing similarity of appearance and will be presumed to have succeeded." ${ }^{39}$ The court then considered the evidence and concluded that '[g]iven the fact that Perfect Fit's product was 'hot,' and given Acme's assiduous efforts to copy Perfect Fit's dress and to cause the public to believe that BedMate was 'the original,' we reject any contention by Acme that public confusion was unlikely."

The Fourth Circuit also presumes a likelihood of confusion from intentional copying. In Osem Food Industries Ltd. $v$ Sherwood Foods, Inc., the defendant admitted copying the trade dress of the plaintiff's dehydrated soup package. ${ }^{61}$ The district court denied the plaintiff's request for a preliminary injunction because, at the time, the Circuit had not explicitly recognized a presumption of a likelihood of confusion arising from intentional copying. On appeal, the Fourth Circuit noted that this "is an issue that has divided the circuits," quoted extensively from $M y-T$ Fine, and concluded that it agreed with Judge Hand's analysis. ${ }^{62}$ The court then explained that "[w] hen a newcomer to the market copies a competitor's trade dress, its intent must be to benefit from the goodwill of the competitor's customers .... Logic requires ... that from such intentional copying arises a presumption that the newcomer is successful and that there is a likelihood of confusion."

58 See, for example, RJR Foods, Inc. $v$ White Rock Corp, 603 F2d 1058, 1060 (2d Cir 1979). But compare Charles of the Ritz Group Ltd. v Quality King Distributors, Inc., in which the court recognized that "[t]his court has held that evidence of intentional copying raises a presumption that the second comer intended to create a confusing similarity," but then remarked that "[a]lthough this factor alone is not dispositive, it bolsters a finding of consumer confusion." 832 F2d 1317, 1322 (2d Cir 1987). Charles of the Ritz Group does not seem to have reversed circuit precedent. See PAF S.r.l. v Lisa Lighting Co., 712 F Supp 394, 408 (S D NY 1989), quoting Mobil Oil Corp v Pegasus Petroleum Corp, 818 F2d 254,258 (2d Cir 1987) (noting that "[i]ntentional copying gives rise to a presumption of likelihood of confusion"); Paddington Corp $v$ Attiki Importers \& Distributors, Inc., 996 F2d 577, 586 (2d Cir 1993) ("Where a second-comer acts in bad faith and intentionally copies a trademark or trade dress, a presumption arises that the copier has succeeded in causing confusion.").

$69618 \mathrm{~F} 2 \mathrm{~d} 950,954$ (2d Cir 1980), citing, inter alia, $M y-T$ Fine, $69 \mathrm{~F} 2 \mathrm{~d}$ at 77.

60 Perfect Fit, 618 F2d at 955.

61 917 F2d 161, 162 (4th $\operatorname{Cir} 1990)$.

62 Id at 164-65.

63 Id at 165. The Fourth Circuit then remanded the case "for the district court to 
As mentioned briefly above, this presumption involves a chain of two analytically distinct inferences. ${ }^{64}$ The first inference is that one who intentionally copies another's trade dress must intend to confuse or deceive consumers. This inference is quite weak, despite the Fourth Circuit's forceful assertion that logic requires such an inference. The second inference is that one who intends to confuse or deceive consumers will likely succeed. This inference, unlike the first inference, is quite strong. Indeed, there are good reasons to conclude that one who intends to confuse consumers will likely succeed. ${ }^{65}$ But, like any chain, the chain of inferences underlying the presumption of a likelihood of confusion from intentional copying is only as strong as its weakest link.

The first inference is weak because there are plausible reasons one might copy a competitor's trade dress other than to confuse consumers. For example, one might copy another's trade dress with the belief that the trade dress is functional and that it is therefore necessary to copy in order to compete in the marketplace. ${ }^{66}$ Thus, an antifreeze manufacturer might copy the shape of a competitor's jug because that shape is convenient for consumers and is less expensive to manufacture than any alternative containers. ${ }^{67}$ Similarly, one might copy a competitor's trade dress with the belief that "it is the custom in a particular industry to package products in a similar manner, [and that] a trade dress done in that style is likely to be generic.. ${ }^{168}$ Thus, since "packaging lime-flavored soda in green twelve-ounce cans is so

reconsider its order denying the preliminary injunction." Id.

b4 See text accompanying note 49. For authorities discussing these inferences, see also McCarthy, Trademarks § 23.34[3] at 23-221 to 23-222 (cited in note 26); Versa Products Co. $v$ Bifold Co. (Manufacturing) Ltd., 50 F3d 189, 206 (3d Cir), cert denied, 116 S Ct 54 (1995); Restatement (Third) of Unfair Competition § 22 \& comment c (1993).

${ }_{65}$ These reasons are discussed more fully below. See text accompanying notes 77-84.

${ }_{66}$ The functionality defense to a claim of trade dress or trademark infringement is that the allegedly infringed trademark or trade dress "lacks good substitutes, either because the product is worth less without it (the circular tire) or because it makes the product cheaper to produce." Landes and Posner, $30 \mathrm{~J} \mathrm{~L} \mathrm{\&} \mathrm{Econ} \mathrm{at} 297$ (cited in note 22). Under these circumstances, courts deny trademark or trade dress protection because such protection would amount to patent protection without any time limit. Id.

${ }^{67}$ First Brands Corp v Fred Meyer, Inc., 809 F2d 1378, 1381-82 (9th Cir 1987). See also Wallace Intl Silversmiths, Inc. v Godinger Silver Art Co., 916 F2d 76, 81 (2d Cir 1990) (holding that a plaintiff "may not exclude competitors from using those baroque design elements necessary to compete in the market for baroque silverware"); W.T. Rogers Co. $v$ Keene, $778 \mathrm{~F} 2 \mathrm{~d} 334$, 338-41 (7th $\mathrm{Cir}$ 1985) (discussing principles underlying functionality doctrine).

68 See Mana Products, Inc. v Columbia Cosmetics Manufacturing, Inc., 65 F3d 1063, 1069-70 (2d Cir 1995). 
common in the soft drink industry,"69 a soft drink manufacturer might copy a competitor's green trade dress in order to signal to consumers that its product is also a lime-flavored soda. Finally, one might copy a competitor's trade dress with the belief that this is the most effective way to inform consumers that one's product is intended to be a lower-priced alternative to the competitor's products. Thus, for example, the manufacturer of a private label skin-care lotion might copy the trade dress of a brand name competitor in order to signal to consumers that its product is similar to, and intended for the same uses as, the brand name competitor's products. ${ }^{70}$

In each of these examples, the manufacturer has an intent other than to confuse but might nonetheless be liable for infringement if the trade dress is neither functional nor generic and the court presumes a likelihood of confusion from the intent to copy. But, in each of these examples, it would be a mistake to infer either an intent to confuse or likelihood of confusion from the mere fact of intentional copying. As these examples show, it simply does not follow that one who intentionally copies the trade dress of a competitor necessarily intends to confuse consumers. Indeed, there may be circumstances where one might copy in order to benefit consumers, by bringing to the market functionally equivalent alternatives, by sending useful information to consumers about the category of products to which a given product belongs, or by facilitating comparisons between competing products of the same category. And it is entirely plausible that such "good copying" would in fact benefit consumers so long as the copied trade dress was not so similar to the original that there would be a genuine likelihood that consumers would be confused. Thus, to infer a likelihood of confusion from intentional copying in these cases could discourage beneficial copying and, thus, harm rather than protect consumers.

Should an intent to confuse nonetheless be inferred from intentional copying in the absence of any plausible explanation? ${ }^{71}$ In Chevron Chemical Co. $v$ Voluntary Purchasing Groups, 1993).

9 Paddington Corp v Attiki Importers \& Distributors, Inc., 996 F2d 577, 583 (2d Cir

${ }^{70}$ See Conopco, Inc. $v$ May Department Stores Co., 46 F3d 1556, 1565 (Fed Cir 1994), cert denied, 115 S Ct 1724 (1995). For a more complete discussion of Conopco, see text accompanying notes 114-18.

71 Professor Perlman's view is that "[a]n intention on the defendant's part merely to copy another's mark provides little basis for any inference unless the act of copying is so lacking in a plausible justification that one might infer an intent to confuse." Perlman, 80 
Inc., for example, the Fifth Circuit indicated that mere copying would support the inference of an intent to confuse since the court could "think of no other plausible explanation for such behavior. ${ }^{.72}$ On its face, such an approach seems to avoid the pitfall of inferring an intent to confuse from mere intentional copying-namely, the failure to recognize that there may be legitimate reasons, unrelated to confusing customers, for such copying. Ultimately, however, inferring an intention to confuse in the absence of a plausible alternative explanation for copying has the same effect as presuming a likelihood of confusion from intentional copying; in both cases, the defendant bears the burden of giving a plausible explanation for intentional copying. This burden, in turn, would discourage beneficial copying unless potential defendants could predict what sorts of explanations courts will consider plausible.

\section{Intent to confuse raises presumption.}

Several circuits reject the notion that the mere intent to copy raises any presumption, but do recognize that an intent to confuse raises a presumption of a likelihood of confusion. Although courts often express this presumption in terms of the defendant's intention to derive a benefit from the reputation or goodwill of the plaintiff, the idea underlying this expression is that the defendant can accomplish this purpose only by confusing or deceiving consumers into mistaking the defendant's product for the plaintiff's. Thus, "[i]n order to raise the inference of a likelihood of confusion, a plaintiff must show that the defendant intended to profit by confusing consumers."?3

Trademark Rep at 472 (cited in note 20). Professor Perlman was a coreporter for the Restatement (Third) of Unfair Competition, which seems to have taken his approach. It provides that "[a] likelihood of confusion should not be inferred from proof that the actor intentionally copied the other's designation if the actor acted in good faith under circumstances that do not otherwise indicate an intent to cause confusion or to deceive." Restatement (Third) of Unfair Competition § 22(2) (cited in note 64). However, comment c adds that "if there is proof of intentional copying with no alternative explanation, an intent to benefit from the other's good will through confusion may be inferred." Id comment $c$.

${ }^{72} 659$ F2d 695, 704 (5th Cir Oct 1981). In a later case, where the district court did find another plausible explanation for a defendant's admitted copying of plaintiff's trade dress and declined to infer a likelihood of confusion, the Fifth Circuit affirmed. See SnoWizard Manufacturing, Inc. $v$ Eisemann Products Co., 791 F2d 423, 428 (5th Cir 1986).

${ }^{73}$ Toho Co. $v$ Sears, Roebuck \& Co., 645 F2d 788, 791 n 2 (9th Cir 1981). For similar holdings in other circuits, see Esercizio $v$ Roberts, 944 F2d 1235, 1242 (6th Cir 1991); Ambrit, Inc. $v$ Kraft, Inc., 812 F2d 1531, 1542 (11th Cir 1986). 
In Esercizio $v$ Roberts, for example, the defendant admitted copying the exterior design of a Ferrari automobile. ${ }^{74}$ In reviewing the district court's finding that the public was likely to be confused by the Ferrari replicas, the Sixth Circuit reasoned that:

Intentional copying, however, is not actionable under the Lanham Act absent evidence that the copying was done with the intent to derive a benefit from the reputation of another. . . . Where the copying . . . is not done to deceive purchasers and thus derive a benefit from another's name and reputation . . . a case of unfair competition is not made out. ${ }^{75}$

This implies that a court may infer a likelihood of confusion only when copying is done with the intent to deceive consumers and thus to derive a benefit from another's name and reputation. ${ }^{76}$

There are good reasons to infer a likelihood of confusion from the intent to confuse or deceive consumers. The fact that a defendant intended to confuse consumers indicates the defendant believed its trade dress to be confusingly similar to the plaintiff's. ${ }^{77}$ In this situation, the defendant "thinks there is at least a possibility that he can divert some business from the senior user-and the defendant ought to know at least as much about the likelihood of confusion as the trier of fact." unless there is reason to believe the defendant is inept, the defendant's belief that consumers will be confused strongly supports the inference that a likelihood of confusion in fact exists.

Furthermore, as a general rule, inferring a likelihood of confusion from proof of an intention to confuse is a simple and effective way to discourage brazen attempts to confuse consumers. Indeed, William Landes and Richard Posner predict that:

[A]llegedly infringing use would be enjoined if the plaintiff . . could show that [the defendant] had adopted its similar trademark with intent to deceive .... This is a case in which the cost of preventing confusion is negative, so that,

74944 F2d 1235, 1239 (6th Cir 1991).

75 Id at 1243 (citation omitted).

${ }^{76}$ Id at 1242 . In Esercizio, this presumption was unnecessary because the plaintiff had produced sufficient independent evidence warranting the conclusion that a likelihood of confusion existed. See id at 1244-45.

${ }_{77}$ Judge Hand made this observation in My-T Fine, 69 F2d at 77. See also text accompanying note 42 .

${ }^{78}$ Little Caesar Enterprises, Inc. v Pizza Caesar, Inc., 834 F2d 568, 572 (6th Cir 1987). 
even if the benefits are slight, prevention is cost justified unless the costs of using the legal system are very high. ${ }^{79}$

Accordingly, the Restatement (Third) of Unfair Competition provides that "[a] likelihood of confusion may be inferred from proof that the actor used a designation ... with the intent to cause confusion or to deceive." ${ }^{\text {} 80}$

In Carillon Importers Ltd. $v$ The Frank Pesce Group, Inc., the plaintiff offered such proof. ${ }^{81}$ The plaintiff alleged that the defendant's Cristall Moscow vodka infringed the trade dress of Stolichnaya Cristall vodka. In considering the defendant's intent, the court noted that the "[e]vidence reveals that some of the Carillon advertisements were literally 'whited out' and modified for use in promoting Cristall Moscow vodka."82 This evidence, in addition to evidence that the defendant made oral representations "to the trade" about the plaintiff, was:

[O]verwhelming evidence of an intent to target Stolichnaya Cristall. When viewed in light of the great similarity in trade dress and the distinctness of the ultra premium vodka market, the only conclusion is that [the defendant] intended to confuse consumers and to lure them into purchasing Cristall Moscow as a result of this confusion. ${ }^{83}$

It is important to recognize that an intent to confuse will ordinarily be difficult to prove by direct evidence. Such an intent might, for example, be proved by testimony that the defendant adopted its trade dress to confuse consumers. Or it might be proved by internal documents, such as a memorandum instructing a graphic designer to create a confusingly similar trade dress.

In the typical case, however, the plaintiff will not find such a "smoking gun," and in the absence of such evidence, it might be tempting to accept evidence of deliberate copying-such as evidence that the plaintiff's product was before the defendant's designer when the allegedly infringing trade dress was de-

79 Landes and Posner, $30 \mathrm{~J} \mathrm{~L} \mathrm{\&} \mathrm{Econ} \mathrm{at} 304$ (cited in note 22).

so Restatement (Third) of Unfair Competition § 22(1) (cited in note 64). Recall, however, that the Restatement does not recognize an inference of a likelihood of confusion from mere intentional copying so long as "the actor acted in good faith under circumstances that do not otherwise indicate an intent to cause confusion or to deceive." Id § 22(2). See also note 71.

B1 913 F Supp 1559 (S D Fla 1996).

82 Id at 1566 .

${ }^{83}$ Id. Ultimately, however, the court followed circuit precedent and presumed a likelihood of confusion from intentional copying. 
signed-as proof of an intent to confuse. ${ }^{84}$ But permitting a plaintiff to prove an intent to confuse with nothing more than evidence of deliberate copying would, of course, discourage beneficial copying in the same way as presuming a likelihood of confusion from intentional copying.

\section{Intent as a relevant factor.}

The Third and Seventh Circuits have explicitly rejected the notion that either an intent to copy or an intent to confuse should raise a presumption of a likelihood of confusion. In American Home Products Corp $v$ Barr Laboratories, Inc., the plaintiff alleged that the defendant's brown ibuprofen tablets infringed the trade dress of the plaintiff's Advil tablets. ${ }^{85}$ On appeal, the plaintiff argued that the district court erred in not presuming a likelihood of confusion from the defendant's intentional copying. The Third Circuit rejected this argument, holding that "[i]n an action for unlawful imitation of product appearance, evidence of defendant's intent does not relieve plaintiff of its burden of proving likelihood of confusion by a preponderance of the evidence." 86 Thus, the court concluded, the trial court "did not err in declining to infer likelihood of consumer confusion from a mere intent to imitate." ${ }^{87}$ Although the court did suggest that the "intent to confuse might be highly probative of likelihood of confusion," it gave no indication that the intention to confuse raised a presumption to this effect. ${ }^{88}$

The Seventh Circuit considered this question in Schwinn Bicycle Co. $v$ Ross Bicycles, Inc. ${ }^{89}$ In Schwinn, the district court, relying on what seemed to be quite explicit circuit precedent, presumed a likelihood of confusion from the defendant's deliberate imitation of the trade dress of the plaintiff's exercise bicycle. The Seventh Circuit vacated and remanded, explaining that "the district judge placed far more emphasis on [the earlier case] than it properly deserves." The court then held that intentional

${ }^{84}$ See P.T.C. Brands Inc. $v$ Conwood Co. L.P., 28 USPQ2d (BNA) 1895, 1905-06 (W D Ky 1993) (finding intent to copy from, among other things, evidence that defendant's designer "had [plaintiff's] package in front of him when he designed the [defendant's] package").

85834 F2d 368, 369 (3d Cir 1987).

86 Id at 371 .

87 Id.

$s$ Id.

89870 F2d 1176, 1184-85 (7th Cir 1989).

so Id at 1183 . 
copying is "but one of the factors bearing on the likelihood of confusion issue" and cited the "[c]onvincing reasoning" of the Third Circuit in American Home Products. ${ }^{91}$ Furthermore, the court added, "the exclusive use of a presumption of consumer confusion ... in granting a preliminary injunction is at odds with the general rule that ' $t$ ] ] granting of a preliminary injunction is an exercise of a very far-reaching power, never to be indulged in except in a case clearly demanding it."'92

The Third Circuit recently revisited the issue in Versa Products Co. $v$ Bifold Co. (Manufacturing) Ltd., a case involving two competing control valves used on offshore oil rigs. ${ }^{93}$ Although the case involved product configuration (and not ordinary product packaging), the court explained that "a defendant's bare intent to adopt a mark or product packaging substantially identical to a plaintiff's mark or packaging" is not a relevant consideration because "there is little basis in fact or logic for supposing from a defendant's intent to copy (without more) that the defendant's actions will in fact result in confusion." "what we have held is that a defendant's intent to confuse or deceive consumers . . . may be highly probative of likelihood of confusion." ${ }^{95}$ The court also rejected "a broader rule holding that a defendant's intent to copy strongly supports an inference of likelihood of confusion" because "the defendant's intent [to copy] standing alone... reveals little about the probable outcome of the defendant's conduct."

While a rule recognizing intent as a mere factor in the likelihood-of-confusion analysis avoids the inferential leaps attendant to the intent-to-copy approach, it nonetheless fails to establish with any clarity under what circumstances a court should find that a likelihood of confusion exists. On this approach, the intent to copy would be a relevant factor if it could support an inference of an intent to confuse. But, since there are other plausible explanations for intentional copying, it is difficult to see how the mere intent to copy (without more) could ever be a material factor. The intent to confuse, on the other hand, is so highly probative of a likelihood of confusion that it makes sense to treat it as more

91 Id at 1183-84 (citations omitted).

92 Id at 1184, quoting Roland Machinery Co. $v$ Dresser Industries, Inc., 749 F2d 380, 389 (7th Cir 1984).

${ }^{83} 50$ F3d 189, 193 (3d Cir), cert denied, 116 S Ct 54 (1995).

24 Id at 205.

95 Id, citing American Home Products, 834 F2d at 371.

$\$$ Versa, 50 F3d at 206. 
than a mere factor..$^{97}$ Thus, a rule recognizing "intent" as a mere factor-whether an intent to copy or an intent to confuse-is truly the worst of the possible rules.

\section{Defendants' Intentions IN THE PRIVATE LaBel ConTeXT}

Private label products pose an interesting challenge to the ways courts conceive of the relationship between intention and likelihood of confusion. Clearly, private label manufacturers intend their products to bear a strong resemblance to their national-brand competitors. At the same time, however, private label manufacturers are not counterfeiters; they are not attempting to make their products identical to the national brands. ${ }^{98}$ They want to get close, but not too close.

\section{A. Cases Involving Private Label Products}

Although there are few reported opinions concerning claims of trade dress infringement against private label manufacturers, there is good reason to believe this scarcity does not accurately reflect the amount of litigation in this area. According to one report, Procter \& Gamble alone prosecuted (and won) twenty-two "package-design" cases within the last several years. ${ }^{99}$ According to another report, a leading private label manufacturer "claims it is threatened with suits about once or twice a year," and settles about 90 percent of them. ${ }^{100}$ It is not surprising that parties settle many of these lawsuits, because until the Federal Circuit's recent decision in Conopco, Inc. $v$ May Department Stores Co., ${ }^{101}$ most of the published cases reflected judicial reluctance to tolerate intentional copying by private label manufacturers. ${ }^{102}$ In-

97 See text accompanying notes 66-70, 77-80.

98 In this context, counterfeiters are those who make "fake" Rolex watches or Louis Vuitton luggage, for example, by copying the trade dress and trademarks of the brand name manufacturer. In contrast, private label products-by definition-bear their own "house" or "private label" brand names.

99 Bernice Kanner, Send In The Clones, Some Courts Say: Brand Names Try To Stay Ahead Of Knockoffs, St. Louis Post-Dispatch 1E, $1 \mathrm{E}$ (Sept 17, 1995). See also P\&G wants copycat brands off shelves, Columbus Dispatch Bus 11, 11 (Nov 21, 1994) (In 1994, Procter \& Gamble "filed a dozen lawsuits to stop parroting of package designs of its shampoos, deodorants, toothbrushes, fragrances, skin-care products and paper towels.... Other large consumer goods companies are echoing P\&G's lead. Unilever Group Plc, for instance . . . files upwards of four dozen suits a year.").

${ }_{100}$ Stern, Cheap Imitation, Wall St J at A1 (cited in note 1).

10146 F3d 1556 (Fed Cir 1994), cert denied, 115 S Ct 1724 (1995). See text accompanying notes 111-18.

${ }_{102}$ See Joseph Diamante and Darren W. Saunders, Four federal court decisions have 
deed, one pair of observers commented that " $[t]$ o the extent private-label manufacturers continue to emulate features of national-brand packaging, they risk judicial findings of intentional copying, which inevitably lead to findings of a likelihood of confusion and trademark infringement or trade dress infringement." ${ }^{\prime 103}$

One example of the courts' willingness to presume a likelihood of confusion from a private label manufacturer's intentional copying is Oral-B Laboratories, Inc. $v$ Mi-Lor Corp. ${ }^{104}$ In Oral-B, the defendant, Mi-Lor, manufactured private label toothbrushes packaged so as to "catch the eye of a potential Oral-B customer. ${ }^{3105}$ The Second Circuit affirmed the district court's finding of a likelihood of confusion, noting that "[t]he view that Mi-Lor's packages are confusingly similar to Oral-B's is strongly supported by Mi-Lor's motive in designing the package. ${ }^{.106}$ The court then concluded that Mi-Lor's obvious intent was to stay as close as it thought it could to Oral-B's packaging and that such "[e]vidence of conscious imitation is pertinent because the law presumes that an intended similarity is likely to cause confusion."107

Another private label case, P.T.C. Brands Inc. v Conwood Co., involved RED LEAF, a private label version of RED MAN chewing tobacco packaged in a red, green, and white pouch similar to the RED MAN pouch. ${ }^{108}$ The district court found the evidence "circumstantially" established Conwood's intent to copy the RED MAN trade dress. ${ }^{109}$ Although the court carefully considered other factors deemed relevant to a likelihood of confusion, it ultimately concluded that, "Conwood's ... intent to copy create[d] a presumption of likelihood of confusion." 110

Finally, in Conopco, Inc. v May Department Stores Co., the defendant packaged and sold its own private label version of

limited the extent to which private-label manufacturers can copy the packaging of their national-brand counterparts, Natl L J B5, B5 (July 18, 1994) (discussing the pre-Conopco state of the law).

${ }^{103}$ Id at B6.

104810 F2d 20 (2d Cir 1987).

${ }^{105}$ Id at 23 (quoting the district judge's description of a statement by the defendant's president).

106 Id.

${ }_{107}$ Id, quoting Harlequin Enterprises Ltd. $v$ Gulf \& Western Corp, 644 F2d 946, 949 (2d Cir 1981).

${ }^{108} 28$ USPQ2d (BNA) 1895, 1899-1900 (W D Ky 1993).

109 Id at 1905.

${ }^{110}$ Id at 1906. The court further concluded that " $[t]$ he evidence permits the inference that Conwood intended to come as close as possible to the packaging of the leading brand RED MAN." Id. 
Vaseline Intensive Care Lotion. ${ }^{111}$ Although the original and revised versions of the defendant's package prominently displayed the "black and white diagonally-striped Venture [Store's] logo," and although the revised version bore the statement "[c]ompare to Vaseline Intensive Care," the two trade dresses were strikingly similar. ${ }^{112}$ The district court, finding that there was "overwhelming evidence that defendants acted with deliberate intent to imitate and infringe," presumed there was a likelihood of confusion. ${ }^{113}$

In each of these cases, the intent to copy is clear. What is not so clear, however, is whether the courts should have presumed a likelihood of confusion from that intent. As discussed above, this presumption depends upon two distinct inferences: that one who intentionally copies another's trade dress must also intend to confuse consumers and that one who intends to confuse consumers will likely succeed. As the earlier discussion demonstrates, however, the first inference is quite weak-for there are a number of explanations for intentional copying other than to confuse consumers. Indeed, in the private label context, there is such an explanation for intentional copying-and it leads to the conclusion that private label manufacturers do not intend to confuse consumers.

\section{B. An Alternative Explanation for Intentional Copying}

An alternative explanation for intentional copying, recognized by the Federal Circuit in Conopco, is that private label manufacturers copy the trade dresses of brand name competitors in order to signal to consumers that their products are lowerpriced alternatives to the brand name products. In Conopco, the Federal Circuit described the private label phenomenon as one:

[I]n which a retailer markets a national brand product and at the same time markets its own private label product in direct competition. The retailer packages its product in a manner to make it clear to the consumer that the product is similar to the national brand, and is intended for the same purposes. ${ }^{114}$

11784 F Supp 648, 658 (E D Mo 1992), rev'd in part, 46 F3d 1556, 1562, 1564-65, 1570-71 (Fed Cir 1994), cert denied, 115 S Ct 1724 (1995).

${ }_{112}$ See Conopco, 46 F3d at 1566, 1567 (reproducing images).

113 Conopco, $784 \mathrm{~F}$ Supp at 678 . It is important to note, however, that the district court did not base its finding solely upon this presumption. See Conopco, 46 F3d at 1566.

11446 F3d at 1565 (emphasis added). 
According to this explanation, the private label manufacturer does not copy with the intent to confuse consumers. On the contrary, the private label manufacturer copies with the intent to aid consumers by providing information about exactly what its product is-a cheaper imitation of the brand name product it resembles. ${ }^{115}$ By imitating the trade dress of a brand name product, the private label product refers to the brand name product it is supposed to replace and thereby shows the consumer "what it's comparable to." and says "I'm a cheaper version of that."

This explanation of intentional copying might not have been as plausible before the emergence of private label products. This, in turn, may explain why, in 1934, it seemed plain to Judge Hand that one who intentionally copied the trade dress of another "could only have meant to cause confusion."117 But the intervening decades since $M y$-T Fine have witnessed such vast changes in the marketplace that the Federal Circuit in Conopco concluded that, "[w]ith the rise of regional and national discount retailers with established names and logos, retailers who market both national brands and their own private label brands in direct competition, this form of competition has become commonplace and well-known in the marketplace."18 Thus, the inference that was obvious to Judge Hand is no longer compelling in today's marketplace.

\section{The descriptive use of trademarks.}

This explanation of intentional copying by private label manufacturers resembles a well recognized doctrine in trademark law that permits the descriptive use of another's trademark. Under

115 Although the Federal Circuit reversed the district court's finding of a likelihood of confusion, the Federal Circuit's rationale was not that the defendant's good intention prevented the inference from intentional copying to intent to confuse. See id at 1566-68. This is probably because the district court's finding was based only in part on the presumption. Instead, the Federal Circuit reversed on the ground that the defendant's logo was sufficiently prominent to dispel any likelihood of confusion. Id.

${ }^{116}$ See Stern, Cheap Imitation, Wall St $\mathrm{J}$ at A1 (cited in note 1) (quoting CEO of private label company).

${ }^{117}$ My-T Fine, 69 F2d at 77.

${ }^{118} 46$ F3d at 1565. The district court in Warner Lambert Co. $v$ McCrory's Corp made a similar observation in evaluating whether there was a likelihood of confusion regarding McCrory's private label version of Listerine, taking "cognizance of the fact that a McCrory's shopper, as with any shopper in such a retail store chain, has likely been exposed to generic or discount house brands before, and . . . is not likely to be misled by the McCrory's mouthwash brand." 718 F Supp 389, 398-99 (D NJ 1989). 
this doctrine, one who copies a competitor's product is free to use that competitor's trademark to inform consumers that the copy is intended to be equivalent to the original product. This use is "descriptive" insofar as the trademark is used to describe the original product to the consumer. This doctrine assumes, of course, that the original product is not otherwise protected (for example, by patent law) and that the trademark itself is not used in a manner that creates a likelihood of confusion among consumers.

In Smith $v$ Chanel, Inc., a leading case involving the descriptive use of a trademark, the defendants "advertised a fragrance called 'Second Chance' as a duplicate of . . 'Chanel No. 5."'119 The Ninth Circuit held that this use of Chanel's trademark for a descriptive purpose did not violate $\S 43(a)$ "so long as it [did] not contain misrepresentations or create a reasonable likelihood that purchasers [would] be confused."

One of the considerations that led the Chanel court to this conclusion is particularly relevant to understanding why private label manufacturers copy the trade dresses of their brand name competitors. Specifically, the court reasoned that since the Chanel perfume was unpatented, the defendants had a right to copy the fragrance, and "[t]here was a strong public interest in their doing so, '[f]or imitation is the life blood of competition. . . .' But this public benefit might be lost"121 if the defendants could not inform potential purchasers that their product was equivalent to Chanel No. 5. The court feared such a result because:

The most effective way (and, where complex chemical compositions sold under trade names are involved, often the only practical way) in which this can be done is to identify the copied article by its trademark or trade name. To prohibit use of a competitor's trademark for the sole purpose of identifying the competitor's product would bar effective communication of claims of equivalence. ${ }^{122}$

The court then concluded that, so long as the two products were equivalent, "the public interest would not be served by a rule of law which would preclude sellers ... from advising consumers of

119402 F2d 562, 562 (9th Cir 1968).

${ }^{120}$ Id at 563. 1959).

${ }^{121}$ Id at 567, quoting American Safety Table Co. $v$ Schreiber, 269 F2d 255, 272 (2d Cir

${ }^{122}$ Chanel, 402 F2d at 567-68 (emphasis added). 
the equivalence and thus effectively deprive consumers of knowledge that an identical product was being offered at one third the price."123

\section{A descriptive-use analysis of trade dress.}

As the Supreme Court observed in Two Pesos, Inc. $v$ Taco Cabana, Inc., § 43(a) "provides no basis for distinguishing between trademark and trade dress." ${ }^{124}$ Since there is "no persuasive reason to apply different analysis to the two," the Court concluded that there is no basis for applying different standards for determining the protectability under $\S 43(\mathrm{a})$ of trade dresses and trademarks. ${ }^{125}$ By the same reasoning, it follows that the descriptive-use doctrine should apply to trade dress as well as to trademark.

Under the descriptive-use doctrine, a manufacturer who copies a competitor's product should be permitted to copy that competitor's trade dress in order to inform consumers that the copied product is equivalent to the original product. Of course, the manufacturer should be permitted to copy the competitor's trade dress only so long as the similarity between the two trade dresses is not so great as to create a genuine likelihood of confusion among consumers. In other words, the manufacturer must be able to get close enough to the competitor's trade dress that consumers will understand the message, but not so close that consumers will be confused.

The Ninth Circuit's reasoning in Chanel explains why a private label manufacturer could have a legitimate competitive need to copy the trade dress of the brand name equivalent of its product. A private label manufacturer, like the defendant in Chanel, is in the business of making equivalents of brand name products, often involving "complex chemical compositions" such as shampoos, mouthwashes, hand lotions, and pain relievers. One way a private label manufacturer can inform consumers that its

${ }^{123}$ Id at 568. On remand, the district court found that Second Chance did not "duplicate[ ] 100\% perfect" the scent of Chanel No. 5 as its advertising had claimed. Thus, while the defendants were not liable for trademark infringement, the court held that they were nevertheless liable under $\S 43(\mathrm{a})$ for false advertising. See Chanel, Inc. $v$ Smith, 178 USPQ (BNA) 630, 633 (N D Cal 1973). This suggests that private label manufacturers who escape § 43(a) liability for trade dress infringement might nonetheless be liable under that section for false advertising if the private label products themselves are not sufficiently equivalent to the brand name products they mimic.

124505 US 763, 773 (1992).

125 Id at 773-74. 
product is equivalent to a national brand is to refer to that brand on the label of its own product. The label on the defendants' product in Conopco, for example, bore the statement "Compare to Vaseline Intensive Care."126 But another way a private label manufacturer can inform consumers of this equivalence is by making descriptive use of the trade dress of the national brand - that is, by using images, rather than words, to tell consumers that its product is equivalent to a particular national brand. ${ }^{127}$

One might respond to this application of the descriptive-use doctrine by arguing that since a private label manufacturer can make descriptive use of a competitor's trademark, there should be no need to make descriptive use of a competitor's trade dress. In some circumstances, however, the descriptive use of a national brand's trade dress may be the only truly effective means of communicating with the consumer. Indeed, a number of courts have recognized that consumers exercise little care when searching for and purchasing inexpensive goods. ${ }^{128}$ It follows that, when

${ }^{126} 46$ F3d at 1567. The plaintiff in Conopco also brought a $\S 43($ a) claim to enjoin this use of its trademark. The Federal Circuit also reversed the district court's finding of a likelihood of confusion on this claim, stating that "[i]f the use [of another's] mark is truthful and unlikely to confuse consumers ... then the use is permissible." Id at 1571. See also Warner Lambert Co. $v$ McCrory's Corp, 718 F Supp 389, 392 (D NJ 1989) (denying plaintiff's motion for a preliminary injunction to prevent defendant from placing its "private label amber mouthwash on shelves with [plaintiff's] Listerine under a 'compare and save' sign").

${ }^{127}$ In a case very similar to Chanel, a defendant manufactured a knock-off version of the Opium fragrance, copied Opium's trade dress, and included a direct reference to Opium on its box. See Charles of the Ritz Group Ltd. $v$ Quality King Distributors, Inc., 832 F2d 1317, 1318 (2d Cir 1987). The district court did not find a likelihood of confusion with regard to the trade dress, in spite of circuit precedent permitting an inference of a likelihood of confusion from intentional copying. Id at 1320 . See also note 58 . The district court did, however, enjoin the reference to Opium on defendant's box. Charles of the Ritz Group Ltd. $v$ Quality King Distributors, Inc., 636 F Supp 433, 437-38 (S D NY 1986). The Second Circuit affirmed the injunction. 832 F2d at 1322.

${ }^{128}$ In Conopco, for example, an expert testified that "[t]he average consumer purchasing inexpensive consumer goods, such as skin care lotions, usually reviews the product for approximately three seconds." $784 \mathrm{~F}$ Supp at 665 . See also id at 678 ("[C]onsumers take less care in shopping for and selecting inexpensive products."); RJR Foods, Inc. $v$ White Rock Corp, 603 F2d 1058, 1061 (2d Cir 1979) ('[T]he products' modest cost was not conducive to the exercise of careful selectivity by purchasers."); Essie Cosmetics, Ltd. $v$ Dae Do International, Ltd., 808 F Supp 952, 959 (E D NY 1992) ("Confusion by purchasers is likely to be greater the cheaper the product, since less care may be taken in selection."); Sykes Laboratory, Inc. $v$ Kalvin, 610 F Supp 849, 860 (C D Cal 1985) ("AA] person purchasing a bottle of nail hardener would not exercise a high degree of care."). Courts often refer to this phenomenon to suggest consumers may be more likely to be confused by similar trade dress when a product is inexpensive. While this phenomenon is important to consider in determining whether there is any likelihood of confusion between two trade dresses, it does not necessarily lead to the conclusion that private label versions of inexpensive 
shopping for such goods, consumers are less likely to read labels carefully and instead rely heavily on the trade dress of inexpensive products as a source of information. ${ }^{129}$ If so, comparative statements-such as "Compare to Vaseline Intensive Care"-may have little effect when displayed on an otherwise dissimilar trade dress. Thus, in order to communicate with consumers more effectively, private label manufacturers often simulate the trade dress of a brand name product, thereby making it easier for consumers to identify its product as an equivalent of the brand name product. ${ }^{130}$

Under this analysis, private label manufacturers do not copy the trade dresses of their brand name competitors in order to confuse consumers. Instead, they copy because copying is the most effective way to inform consumers that their products are equivalents of national-brand products. If this analysis is correct, courts should not presume a likelihood of confusion from the mere fact that private label manufacturers copy the trade dresses of their brand name counterparts because the first of the two inferential steps underlying this presumption-namely, that an intent to copy necessarily implies an intent to confuse-is invalid.

If courts do presume a likelihood of confusion from intentional copying by private label manufacturers, they will discourage private label manufacturers from using what is perhaps the most effective means of communicating their claims of equivalence to consumers. This, in turn, could harm consumers by depriving them of useful information, by causing private label manufacturers to raise prices in order to cover increased advertising expenditures, and perhaps even by causing private label goods to disappear from the marketplace altogether. ${ }^{131}$ Courts should instead apply the descriptive-use doctrine and thereby allow pri-

brand name products will cause such confusion. This is especially true if consumers are familiar with the presence of private label products in the marketplace. See text accompanying note 118 .

12 Contrast Litton Systems, Inc. $v$ Whirlpool Corp, 728 F2d 1423, 1446 (Fed Cir 1984) (Distinguishing the products at issue-microwave ovens-the court observed that " $t]$ here may be, and doubtless are, products whose consumer buyers would take little notice of a maker's name or disregard a name plainly evident to the buyer's eye.").

130 This may explain in part the disappearance of the "generic product" in its no-frills packaging. See Stern, Cheap Imitation, Wall St J at A1 (cited in note 1) ("Generic products, in stark black-and-white packages, were all the rage for about the blink of an eye in the '70s, but quickly faded away because of their reputation as low-quality, charmless substitutes.").

131 Private label goods might disappear from the marketplace if the higher prices required in order to cover advertising costs deprive private label products of their competitive advantage as lower-priced alternatives to brand name products. 
vate label manufacturers to use trade dress to convey their claims of equivalence to consumers. ${ }^{132}$

\section{Objections and Replies}

It is undeniable that allowing intentional copying of trade dresses would permit private label manufacturers to free ride on the investments of their brand name competitors in developing consumer recognition of brand name products in the marketplace. There are two noteworthy objections to permitting such free riding. First, some courts have suggested that free riding is an inherently unfair form of competition and is thus contrary to the purpose of the Lanham Act. Second, several commentators have argued that free riding undermines the effectiveness of trade dress as an indicator of source and quality and that allowing such trade practices will discourage brand name manufacturers from developing strong trade dresses. Both of these objections merit response.

\section{Intentional copying is inherently unfair.}

The notion that intentional copying by private label manufacturers is inherently unfair was advanced by a district court in Kroger Co. $v$ Johnson \& Johnson. ${ }^{133}$ In Kroger, the plaintiffs sought a declaratory judgment that their private label versions of Tylenol, sold under the names "Actenol," "Supernol," and "Hydenol," did not infringe the name or trade dress of the defendant's Tylenol. The plaintiffs admitted that the names and packaging of their private label products were intended to be

132 Of course, manufacturers will still be liable under $\S 43(\mathrm{a})$ if their trade dresses are so similar to those of their brand name competitors that there is a genuine likelihood of confusion. One might question whether this descriptive-use analysis-since it would permit the copying of a brand name product's trade dress-would also permit a private label manufacturer to copy the name of the brand name product. For example, if a private label manufacturer can copy the trade dress of Tylenol, should the manufacturer also be able to copy the name "Tylenol"? The answer is that the descriptive-use analysis would permit copying of the name "Tylenol"-but for the fact that such copying would, without question, create a likelihood of confusion. However, nothing should prevent a private label manufacturer from copying elements of a name for descriptive purposes-so long as this copying does not create a genuine likelihood of confusion. Thus, a private label manufacturer might use the suffix "nol" to indicate to consumers that its product is intended to be equivalent to Tylenol-so long as this use is not likely to confuse consumers. See Kroger Co. v Johnson \& Johnson, 570 F Supp 1055, 1056-57 (S D Ohio 1983) (plaintiffs, manufacturers of private label versions of Tylenol, called "Actenol," "Supernol," and "Hydenol," seeking a declaratory judgment, and losing on other grounds).

133570 F Supp 1055, 1060 (S D Ohio 1983). 
"reminiscent of Tylenol."134 Furthermore, the plaintiffs admitted that they believed a similar trade dress "would help [consumers] associate in their mind the fact that this product was not only similar to Tylenol, but similar to a particular size or a particular shape."135

Although circuit precedent recognized that the intent to derive benefit from the reputation of another could justify a finding of a likelihood of confusion in the trademark context, ${ }^{136}$ the district court did not invoke that presumption. Instead, the court condemned the plaintiffs for attempting to free ride on the defendant's investment in promoting consumer goodwill toward Tylenol. According to the court, there was "something inherently unfair in the effort by plaintiffs to avail themselves of the name and good will of Tylenol." ${ }^{\text {"137 }}$ After all, the "[d]efendants ha[d] expended millions of dollars in advertising their product to the American public." Thus, the court concluded, "[t]o permit a bystander who has spent a minimum of time, money, and effort in developing its product to profit by marketing the identical commodity with a similar name and packaging is contrary to the stated Congressional purpose of the Lanham Act"138 which, the court had previously noted, is to "protect persons engaged in [ ] commerce against unfair competition."

Despite the Kroger court's belief that free riding on a competitor's goodwill is somehow "inherently unfair," the Supreme Court had long before rejected that idea. In Kellogg Co. $v$ National Biscuit Co., the "Shredded Wheat case," the National Biscuit Company had sought to enjoin allegedly unfair competition by Kellogg, who had manufactured shredded wheat in a pillow-shaped form and called its product "Shredded Wheat."140 After determining that National Biscuit did not have an exclusive right to either the term "Shredded Wheat" or the form of the pillow-shaped biscuit, the Court considered whether Kellogg was nonetheless engaging in unfair competition. ${ }^{141}$ The Court found

134 Id at 1059.

135 Id at 1060.

${ }^{136}$ See Frisch's Restaurants, Inc. v Elby's Big Boy, 670 F2d 642, 648 (6th Cir 1982), quoting Cheuron, 659 F2d at 704 ("[I]f the mark was adopted with the intent of deriving benefit from the reputation of [another], that fact alone may be sufficient to justify the inference that there is confusing similarity.").

${ }^{137}$ Kroger, 570 F Supp at 1060.

138 Id.

139 Id at 1058, citing 15 USC $\S 1127$ (1982).

140305 US 111, 113 (1938).

111 Id at 116-20. 
that the Kellogg name was sufficiently prominent on the defendant's packaging to "minimize the possibility of confusion, ${ }^{142}$ and then rejected the notion that Kellogg should nonetheless be prevented from sharing in the goodwill of shredded wheat:

Kellogg Company is undoubtedly sharing in the goodwill of the article known as "Shredded Wheat"; and thus is sharing in a market which was created by [ ] skill and judgment ... and has been widely extended by vast expenditures in advertising persistently made. But that is not unfair. Sharing in the goodwill of an article unprotected by patent or trade-mark is the exercise of a right possessed by all-and in the free exercise of which the consuming public is deeply interested. ${ }^{143}$

Although Kellogg was a pre-Lanham Act case, it clearly states that free riding on the goodwill of another, even if that goodwill was developed at great expense, is not inherently unfair.

A district court recently applied the same rationale to protect the descriptive use of a trademark on a generic nail hardener. In Sykes Laboratory, Inc. $v$ Kalvin, the defendant marketed "low cost versions of name-brand beauty products" under the name "the GENERIC BRAND."144 The packaging of the defendant's product made descriptive use of the plaintiff's name and brand name. ${ }^{145}$ In rejecting the plaintiff's trademark infringement claim, the court explained that "[o]ne consequence of the rule announced in [Chanel] is that the copyist may freely capitalize on the goodwill and product recognition developed at great cost by the trademark owner."146 Furthermore, the court noted, "[b]y

${ }^{142}$ Id at 121.

143 Id at 122.

14610 F Supp 849, 851 (C D Cal 1985).

${ }^{145}$ Id at 852 (For example, the defendant's box included the phrase "the GENERIC BRAND tm Version of Sykes' 'Perfect Nail' (R).").

${ }_{146}$ Id at 854, citing Monte Carlo Shirt, Inc. $v$ Daewoo International (America) Corp, 707 F2d 1054, 1057 n 3 (9th Cir 1983) ("[T] here are [ ] circumstances in which a competitor is permitted to benefit from the good will of the trademark owner. For instance, a manufacturer can market a duplicate of a nonpatented trademarked product and inform the public that it is identical to the trademarked product."). See also Anti-Monopoly, Inc. $v$ General Mills Fun Group, 611 F2d 296, 301 n 2 (9th Cir 1979) ("The owner of a widely recognized trademark cannot [ ] prevent a competitor from referring to the owner's mark.... This is so despite the benefits which the competitor reaps from the product recognition engendered by the owner's popularization, through expensive advertising, of the mark."). 
taking his 'free ride,' the copyist ... serves an important public interest offering comparable goods at lower prices."147

As these cases demonstrate, courts have rejected the notion that free riding on a competitor's goodwill, when the competitor's investment is otherwise unprotected by law, is an inherently unfair form of competition. ${ }^{148}$ Although "at first glance it might seem intolerable that one manufacturer should be allowed to sponge on another by pirating the product of years of invention and development... this initial response to the problem has been curbed in deference to the greater public good." is not inherently unfair-at least with regard to the "unfair competition" prohibited by the Lanham Act-for a private label manufacturer to free ride on the goodwill and consumer recognition of brand name products (assuming, of course, that the private label product does not create a genuine likelihood of confusion).

Indeed, this type of free riding serves the greater public good by promoting increased competition. After all, permitting private label manufacturers to copy the trade dresses of brand name products helps those manufacturers inform consumers that cheaper alternatives to brand name products are available in the marketplace. ${ }^{150}$ If consumers are thus better informed about the

147 Sykes Laboratory, 610 F Supp at 854, quoting Chanel, 402 F2d at 568.

${ }_{118}$ A related criticism is that intentional copying is inherently unfair because it involves a subtle form of confusion: consumers are tricked into "associating" the private label product with the brand name product. See Samuel D. Rosen and Lisa M. Gigliotti, Conopco-Kaputco for Trade Dress Plaintiffs?, 85 Trademark Rep 135, 141 (1995). This criticism misses the mark in two ways: First, it assumes private label manufacturers lead consumers to "associate" their products with brand name products rather than make descriptive use of competitors' trade dresses. Second, it assumes such "association" is tantamount to confusion-which it quite obviously is not. After all, a consumer might see a private label version of Vaseline Intensive Care Lotion, and "associate" that trade dress with the brand name product, and yet not be confused in any way.

${ }^{149}$ American Safety Table Co. $v$ Schreiber, 269 F2d 255, 271-72 (2d Cir 1959). The court continued:

For imitation is the life blood of competition. It is the unimpeded availability of substantially equivalent units that permits the normal operation of supply and demand to yield the fair price society must pay for a given commodity. Unless such duplication is permitted, competition may be unduly curtailed with the possible resultant development of undesirable monopolistic conditions.

Id at 272 (citations omitted).

${ }_{150}$ Inevitably, at least a few consumers will be confused by private label copies who would not be confused if such copying were prohibited. It is important to balance the costs of such an increase in confusion against the benefits of a potential increase in competition. However, it is also important to recognize that even a moderate increase in confusion may diminish over time as consumers become more familiar with the presence of private label copies in the marketplace. 
available alternatives, brand name products will have to compete with private label products in order to attract and retain customers. This, in turn, will likely result in increased price competition between private label products and their brand name counterparts. Thus, even if a consumer chooses a brand name product rather than a competing private label version, the consumer will likely pay less for the brand name product than if there were no such competition.

\section{Intentional copying discourages strong trade dress.}

Some critics of the Federal Circuit's decision in Conopco have said that the court's opinion "can only be characterized as an attack on the importance of trade dress as a source identifier to consumers."151 By permitting the defendants to copy the Vaseline Intensive Care package, these critics argue, the court allowed the defendants "to freely capitalize on Conopco's well-recognized trade dress in order to gain a market place advantage and, in the process, destroy the commercial advantage Conopco had painstakingly created."152 Ultimately, these critics conclude that, if the law permits private label manufacturers to make use of others' trade dresses, "no brand will have the incentive to expend millions of dollars to create and promote its indicia and instead, we will live in a complete, no-name, generic world."153

Indeed, this criticism can be taken one step further. One could argue that reducing the incentive for brand name manufacturers to create strong trade dresses will reduce the incentive for these manufacturers to produce high-quality goods. This, in turn, would reduce the average quality of goods in the marketplace. Indeed, Landes and Posner have observed that one benefit of trademark (and, implicitly, trade dress) protection is that it creates an incentive for manufacturers to improve and maintain the quality of their products. ${ }^{154}$ Thus, one might argue, permitting

151 Rosen and Gigliotti, 85 Trademark Rep at 140 (cited in note 148).

${ }^{152}$ Id.

133 Id at 144. See also Landes and Posner, $30 \mathrm{~J} \mathrm{~L} \mathrm{\&} \mathrm{Econ} \mathrm{at} 270$ (cited in note 22) ("If the law does not prevent it, free riding will eventually destroy the information capital embodied in a trademark, and the prospect of free riding may therefore eliminate the incentive to develop a valuable trademark in the first place.").

${ }^{154}$ See Landes and Posner, $30 \mathrm{~J} \mathrm{~L} \mathrm{\&} \mathrm{Econ} \mathrm{at} 280$ (cited in note 22):

[A] firm that was producing a lower-quality brand might attempt to free ride on firms producing higher-quality brands by duplicating their trademarks and hoping that consumers would be misled into believing the brands were equivalent. Since this would make it more costly for consumers to distinguish higher-quality from lower- 
private label manufacturers to make descriptive use of their brand name competitors' trade dresses could ultimately reduce the quality of goods available to consumers.

Although it is impossible to say with certainty that permitting private label manufacturers to copy the trade dresses of brand name products will not have these deleterious effects, there are reasons to doubt this pessimistic forecast. ${ }^{155}$

First, although free riding by a private label manufacturer would likely reduce the ability of a brand name manufacturer to recover all of the profits associated with a strong trade dress, there is no reason to believe this free riding will eliminate the incentive to develop a strong trade dress in the first place. So long as brand name manufacturers receive some benefit in excess of their costs, they will have an incentive to cultivate consumer recognition of their products. Thus, while permitting private label manufacturers to copy the trade dresses of their brand name competitors may somewhat diminish brand name manufacturers' incentives to create strong trade dresses, there is little risk that, by permitting such copying, ours will become a "complete, noname, generic world."

Furthermore, there is no reason to expect that permitting a private label manufacturer to make descriptive use of a brand name trade dress will destroy the function of trade dress as an indicator of source or quality. This is because, under the descriptive-use analysis, the private label manufacturer copies a competitor's trade dress in order to refer to the competitor's brand name product. This should reinforce, not undermine, the strength of the brand name product's trade dress as an indicator of source and quality because, in effect, the private label product is indicating that the brand name product is "the one to copy."

\section{CONCLUSION}

The presumption of a likelihood of confusion from intentional copying has outlived its usefulness. With the explosion of private label manufacturing, it no longer makes sense to infer that one

quality brands, it would lower the incentive for a firm to incur the added cost that would be necessary to produce a higher quality. Hence, the average quality of the product as a whole would be lower.

155 These reasons assume, of course, that private label manufacturers will not come so close to the trade dresses of brand name products that there is a genuine likelihood of confusion. This Comment has already asserted that such use would subject a manufacturer to legal liability in any case. 
who deliberately copies the trade dress of a competitor does so with the intention of confusing consumers. By copying the trade dresses of their brand name competitors, private label manufacturers can effectively describe to consumers the brand name products to which their private label products correspond. A presumption of a likelihood of confusion from intentional copying would discourage such instances of beneficial copying and therefore harm rather than protect consumers by depriving them of information about-and access to-lower-cost alternatives to brand name products. Thus, unless a clear intent to confuse consumers is proved by direct evidence, courts should decline to infer anything at all from evidence of intentional copying. Instead, courts should focus their efforts on the real issue: whether two trade dresses are so similar as to create a genuine likelihood of confusion among consumers. 